receptor and the $\beta$-adrenergic receptors, and their relation to adenylcyclase, through opiate and prostaglandin receptors, to the inhibition of adenylcyclase in Escherichia coli by glucose. Interesting though the latter effect is in relation to catabolite regulation in microbes, its relevance to the adenylcyclase system of animals is questionable.

Throughout one is struck by the careful balance achieved in each section, which reflects as much credit on the Chairman of the Program Committee (Purnell W. Choppin), as on the two editors concerned with the production of the book. It is becoming increasingly apparent that no biochemist, whatever his field, can afford to ignore the subject of membranes. This account of the most important components of surface membranes-the cellular receptors-will be appreciated by a wide audience. The financial contribution of Miles Laboratories towards the symposium was worth while and timely. Perhaps they might be encouraged to extend their patronage of subsequent symposia to underwriting part of the production costs. In that case, the scientific community at large will benefit as much from their generosity as the participants of the symposium.

C. A. Pasternak

\title{
Acute diarrhoea in childhood
}

Edited by Katherine Elliott and Julie Knight. 1976. Ciba Foundation Symp. no. 42 (new series). Amsterdam, Oxford and New York: Elsevier. Pp. 375 . US \$26.95.

The recent explosion of knowledge of infantile gastro-enteritis has several sources, notably in the pathophysiology of cholera, in the aetiology of diarrhoea of domestic animals, in viral causes of diarrhoea and in mucosal defence-mechanisms. The Ciba Foundation rightly judged the time ripe for one of its famous symposia, held in London in October 1975 and now published as a book full of good things. The largest emphasis is on cholera and ion transport (four papers) and on viral gastro-enteritis (five papers). Many other aspects are discussed, and the proceedings would almost serve as a general account of modern views on gastro-enteritis but for one curious omission; although much mention is made of Escherichia coli infection there is no specific discussion of the significance of enterotoxin production by $E$. coli in human diarrhoeal disease. The individual papers are nearly all excellent, authoritative and up to date, and the discussions largely avoid the embarrassing banality which lively encounters at a meeting so often assume in cold print. Moreover, the editors avoid a common annoyance of printed discussions by including references to the discussion points as well as the main texts. It may be invidious to pick out one paper from so many good ones, but the closing contribution from Jon Rohde, called "Taking science where the diarrhoea is", does deserve special mention. While acknowledging the major success by which fundamental transport studies led to the use of oral glucose-electrolyte solution in the field, he shows how many gaps there are between ideas and their application. A broad ecological and sociological view is essential if research in diarrhoeal disease is to lead to improved child health in the poor countries of the world.

H. P. LAMBerT

The role of culture collections in the era of molecular biology

Edited by Rita R. Colwell. 1976. Washington D.C.: American Society for Microbiology. Pp. vii and 76 . US $\$ 12$.

Despite its rather misleading title, this slim volume is not a textbook but thirteen contributions to a souvenir volume to celebrate the 50th Anniversary of the American Type Culture Collection (ATCC) held in September 1975. They are a stimulating and speculative set of essays; some deal directly with culture collections and others more remotely.

An entertaining foreword by S. T. Cowan is followed by a brief account of the history of the ATCC by its Director, Richard Donovick. C. Lamanna stresses the museum aspect 
of culture collections, J. R. Porter the historical and international aspects leading to the formation of the World Federation of Culture Collections with the sponsorship of international organisations and UN agencies, and R. R. Colwell deals with the use of electronic data-processing in biological collections, and of computers in microbiology in general. The remaining essays are heterogeneous, and illustrate the importance of the ATCC as a major culture collection and the wide range of organisms that it maintains: bacteria, viruses, fungi, algae, protozoa (discussed speculatively by $\mathbf{S}$. H. Hutner), and tissue cell lines (on which L. Hayflick writes imaginatively of the future).

H. J. Carlson and A. L. Demain stress the value of the culture collections for the conservation of the genetic resources of micro-organisms, the latter particularly from industrial aspects such as mutant preservation and genetic engineering. E. P. Odum discusses genetic diversity in ecosystems. R. G. E. Murray writes on recent advances in comparative cytology, and R. Dubos on bacterial polymorphism. J. Liston presents an account of the developments in taxonomic approach in the successive editions of Bergey's Manual, the latest edition (8th) of which gives the culture collection designations of type strains.

This collection of essays, which look both at the past and into the future, can be recommended for borrowing from libraries as an intellectual aperitif, and as a demonstration of the vital role that culture collections play in microbiology.

STEPHen LAPAgE

Modern views on microbial pathogenicity

By H. Smith. 1976. Meadowfield Press, Shildon, County Durham. Pp. vi and 42. $£ 1 \cdot 90$.

\section{Bacteral conjugation}

By D. J. Finnegan. 1976. Meadowfield Press, Shildon, County Durham. Pp. vi and 42. $£ 1 \cdot 90$.

\section{Yield studies in micro-organisms}

By A. H. Stouthamer. 1976. Meadowfield Press, Shildon, County Durham. Pp. viii and 88. $£ 2 \cdot 80$.

It is common enough to want something for nothing, and these days we are thankful to get anything at all for less than $£ 2.00$. According to these criteria, therefore, the reader picks up these three booklets with some interest and even a shade of disbelief. All three are part of a series called "Patterns in progress". Each deals with a relatively limited facet of modern microbiology, and the three reviewed here are the first of thirteen that are either already published or in the course of preparation. In practice, they seem broadly to fall into two categories: booklets of about 40 pages, as is the case with the first two reviewed here, and more solid contributions of approximately twice this length, as is the case with the third.

The three booklets take rather different approaches to their subjects. Professor Smith's book concerns the broadest topic of the three and is the most discursive. He analyses the determinants of microbial pathogenicity inasmuch as anything is known about them. The most valuable aspect of the booklet is that-perhaps unintentionally-it reveals rather clearly that quantitative studies on the interaction of living systems-such as is exemplified by human diseases of microbial origin-is still all but impossible and that the experimental approach to the subject is fraught with difficulty. Nevertheless, this is a succinct and informative account of a developing field of microbiology and clearly the field covered is highly relevant for practising medical microbiologists.

Finnegan deals briefly with a very much more limited topic-bacterial conjugation. This is a strictly factual account of an interesting microbiological phenomenon from the viewpoint of a molecular biologist, and all is correct if significantly out of date by now. The account seems rather eclectic, because it makes no attempt to assess the importance 